\title{
Isabel Angola e Margarida Crioula: duas escravas mandingueiras na Capitania de Goiás (1783-1804)
}

Isabel Angola and Margarida Crioula: two mandingueiras slaves in Captaincy of Goiás (1783-1804)

\author{
Daniel Precioso \\ https://orcid.org/0000-0003-1605-7135 \\ Universidade Estadual de Goiás
}

Resumo: $\mathrm{O}$ artigo analisa a presença africana em Goiás a partir das práticas religiosas de sacerdotes e curandeiros. À luz dos trabalhos de Luís Nicolau Parés, João José Reis e Ira Berlin analisamos indícios presentes em fontes manuscritas de arquivos goianos sobre duas mandingueiras cativas. As principais questões que nortearam a pesquisa foram: quais eram as práticas religiosas realizadas por essas escravas em Goiás colonial? Em que medida as tradições religiosas africanas foram ressignificadas em território goiano? Conclui-se que, apesar da prevalência dos pretos minas, os angolas também desempenharam um papel importante nas práticas mágicas ressignificadas na região em análise. O envolvimento de crioulos em tais práticas sugere, ainda, a operacionalidade do "modelo pendular" de Ira Berlin, assim como uma relativização da afirmação de que a crioulização redundava em ladinização.

Palavras-chave: Diáspora atlântica. Bolsas de mandinga. Ressignificação de práticas mágicas.

\begin{abstract}
The article analyzes the African presence in Goiás from the religious practices of priests and healers. From the works of Luis Nicolau Paredes, João José Reis and Ira Berlin, the article analysis sources present in handwritten of archives about two captive mandingueiras. The main questions that guided the research were: what were religious practices by these slaves in colonial Goias? To what extent have African religious traditions been reassigned in Goiás territory? In conclusion, even so the presence of Minas, Angolans also plays an important role in the magic practices ressignified in the region under analysis. The involvement of Creoles also suggests the application of the "pendulum model" of Berlin, as well as a relativity of the affirmation of a redundant creolization in ladinization.
\end{abstract}

Keywords: Atlantic diaspora. Bags of mandinga. Re-signification of magical practices

As minas de Goiás integravam o "complexo da mineração". Sua história está, assim, imbricada com as de Minas Gerais e de Mato Grosso. Ao avançarem sobre o sertão dos Goyazes, além do interesse pelo ouro e pela expansão da fé e da lei, os colonizadores portugueses miravam o alargamento das fronteiras coloniais a oeste, adiante dos limites territoriais traçados pelo Tratado de Tordesilhas (LEMES, 2003, p. 195-196 e 204). Desde os achados auríferos da década de 1720, as autoridades régias debateram a necessidade de criar uma capitania autônoma, tendo em vista a grande extensão da jurisdição da Capitania de São Paulo, à qual pertenciam as minas de Goiás. A Coroa portuguesa optou, porém, pela criação de uma vila (Vila Boa de Goiás) em 1739, postergando a criação da capitania. A autonomia jurisdicional das minas de Goiás foi adquirida em meados do século XVIII em uma jogada de dois lances: a criação da

Esta obra está licenciada sob uma Creative Commons - Atribuição 4.0 Internacional 
Prelazia de Goiás em 1746, desvinculada do Bispado de Mariana; e a criação da Capitania de Goiás em 1748, desmembrada da de São Paulo'.

Em Goiás, a exemplo do que ocorreu em Minas Gerais, ainda que em menor volume, a exploração aurífera ensejou a importação de uma ampla camada de africanos escravizados, os quais alcançavam os centros mineradores goianos principalmente pelo caminho da Bahia. Confirmando a conhecida preferência dos mineiros por escravos de "nação mina" (isto é, oriundos da Costa da Mina e da Costa dos Escravos, na África Ocidental $)^{2}$, os escravos dessa procedência eram os mais frequentes nas minas de Goiás. De acordo com os registros de batismo de escravos (1765-1820) existentes no Arquivo Geral da Diocese de Goiás, "78\% dos declarados pretos (africanos) nos batismos correspondem aos minas. Angolas, nagôs e congos totalizam 3\%. Os pretos cuja nação não foi especificada somam 19\%" (LOIOLA, 2009, p. 46). O baixo percentual de Angolas e Congos, contudo, não deve ser sobrevalorizado, tendo em vista que muitos africanos escravizados nessas regiões já vinham batizados para a América portuguesa. Com a decadência da mineração ${ }^{3}$ e a mudança do eixo da economia goiana dos núcleos urbanos mineradores para as atividades agrícolas, entre a vinda da Coroa portuguesa para o Rio de Janeiro (1808) e a abolição do tráfico internacional de escravos (1850), os crioulos (nascidos no Brasil) passaram a preponderar numericamente em meio à população escrava da Capitania - depois de 1821. Província - de Goiás. As taxas de manumissão também eram elevadas, sendo a população livre maior do que a escrava ao tempo da vinda da corte portuguesa para o Rio de Janeiro, em 1808 (PALACIN, 1972). Os crioulos, como nas demais capitanias, eram os que mais frequentemente se alforriavam, mesmo no tempo em que a esmagadora maioria dos escravos era de origem africana (LOIOLA, 2009, p. 71).

Não é fortuita a preferência dos mineradores pelos escravos oriundos da Costa da Mina e da Costa dos Escravos, afinal, existiram nessas regiões grandes impérios (Gana, Mali e Songhai) assentados no comércio de ouro entre os séculos IX e XVI. A experiência em mineração dos escravos minas (cujo termo incluía populações oriundas dos atuais Estados-nação de Gana, Togo, Benin e Nigéria) explica, assim, a predileção dos mineiros de Goiás por escravos oriundos do Sudão Ocidental. No início do século XIX, o Barão de Eschwege notou que toda a tecnologia de extração mineral das Minas Gerais era africana (ESCHWEGE, 1899). Os africanos escravizados não realizavam na América apenas trabalhos que requeriam esforço físico, empregando também os seus saberes técnicos em mineração e metalurgia. Em Goiás, alguns escravos - como o

\footnotetext{
${ }^{1}$ Fernando Lobo Lemes (2003, p. 192) observou que a criação simultânea das capitanias de Goiás e Mato Grosso, em 1748, faz parte do projeto de expansão da fronteira a oeste, levado a termo pela Coroa portuguesa a partir de meados do século XVIII.

2 Os africanistas Robin Law (2006, p. 98-120) e Gwedolyn Midlo Hall (2005, p. 29-70) notaram que, entre os escravos de nação mina, não se incluíam apenas os falantes de gã-adangbe (Acra) e línguas akan (fante, twi ou ashante, etc.), mas também gbe (ewe, fon e adja) - ambas pertencentes ao ramo kwa do tronco congo-nigeriano, de acordo com a classificação do linguista norte-americano Joseph Greenberg. Cabe salientar que, na América portuguesa, o termo de procedência "mina" agrupava homens e mulheres de diferentes etnias da África Ocidental. Em Minas Gerais, circulou um dicionário jejê, o que demonstra a importância da língua fon entre a sua população escrava. No Rio de Janeiro, os "minas" também poderiam ser iorubas (provenientes do reino de Oió), os quais, na Bahia, eram chamados de "nagôs". No Maranhão, como já havia observado Raimundo Nina Rodrigues, praticamente todos os africanos ocidentais eram chamados de "minas", referindo-se o termo, sobretudo, aos oriundos do reino fon do Daomé.

3 A "decadência da mineração" não ocasionou a decadência de Goiás. A partir de 1790, a atividades econômicas da capitania voltaram-se à agricultura - o que não significa que elas não existissem no auge da mineração, quando aliás, eram responsáveis pela maior parte da fortuna da capitania. As atividades agrícolas estavam presentes na hinterlândia dos núcleos urbanos, como, por exemplo, no Arraial de Curralinho, próximo à capital, Vila Boa de Goiás.
} 
"negro" Vitorino, de alcunha "Cafelix", do Arraial do Pilar - utilizaram seus conhecimentos sobre metalurgia para burlar a lei. O referido escravo, pertencente ao padre Antônio Rodrigues Posso, foi preso por fabricar ouro falso, como viria a confirmar em interrogatório de 25 de julho de $1752^{4}$.

Se a mineração e a metalurgia estavam nas mãos, sobretudo, dos "pretos minas", as práticas religiosas e de cura eram compartilhadas com os de "nação Angola" e os seus filhos crioulos de primeira geração. Em 1774, o então governador da Capitania de Goiás, José de Almeida Vasconcelos de Soveral e Carvalho, enviou um ofício ao Conselho Ultramarino, denunciando que, na falta de médicos na capitania, os mineiros e os roceiros se serviam de escravos como "enfermeiros" para o tratamento de alguns males ${ }^{5}$. Curandeiros africanos eram, quase sempre, também sacerdotes. Como em África, constituíam autoridades não apenas na religião, mas também na arte da cura na realidade, não havia uma distinção entre religião e cura em África, já que as enfermidades eram lá explicadas não por razões biológicas, mas "espirituais"6. Grande parte dos africanos (cativos ou forros) participava das irmandades católicas, mas, embora professassem a fé cristã, mantinham ativas algumas das suas práticas religiosas tradicionais. Não sem razão, é creditada às irmandades de pretos do período escravista a constituição de alguns "candomblés de nação", como sugere o caso baiano ${ }^{7}$.

Em fins do século XVIII, "devotos pretos" de Nossa Senhora do Rosário, em pleno sertão goiano, praticaram lado a lado o catolicismo e o vodum. Margarida, escrava crioula, e outros irmãos da irmandade do Rosário participavam do ritual daomeano do vodum ressignificado em terras goianas, aceito e tolerado pela população e clero local até os seus praticantes serem denunciados pelo uso de uma "bolsa de mandinga". Como observou Cristina de Cássia Moraes, vislumbram-se aí as relações culturais a partir das práticas dos grupos de sudaneses que se organizaram em irmandades de devoção a santos católicos, e que nos interstícios reconstruíram o culto a seus antepassados (loas), recriando em Goiás de fins do século XVIII, o ritual da árvore sagrada mapu (MORAES, 2002, p. 71-92) .

Apesar das contribuições historiográficas recentes, ainda são poucos os estudos que abordam as práticas culturais dos africanos - cativos ou forros - na Capitania e Província de Goiás. É visando suprir essa lacuna que este artigo propõe uma análise das práticas mágicas africanas em solo goiano. À luz dos trabalhos de Luís Nicolau Parés, João José Reis e Ira Berlin, analisamos indícios presentes em fontes manuscritas de arquivos goianos sobre duas mandingueiras cativas: uma da segunda metade do

\footnotetext{
${ }^{4}$ Ofício do intendente do arraial do Pilar, Anastácio da Nóbrega, ao secretário de estado da Marinha e Ultramar, Diogo de Mendonça Corte Real, sobre terem passado guias do ouro extraído em Janeiro, acerca do qual deveria ser cobrado o quinto, e a devassa que levantou no arraial do Pilar, descobrindo que um escravo do padre António Rodrigues Posso, de nome Vitoriano, produzia ouro falso, 30/07/1752, Arquivo Histórico Ultramarino (AHU), Avulsos da Capitania de Goiás, cx. 7, doc. 544.

${ }^{5}$ Ofício do governador e capitão-general de Goiás, barão de Mossâmedes, José de Almeida Vasconcelos de Soveral e Carvalho, ao secretário de estado da Marinha e Ultramar, Martinho de Melo e Castro, sobre as dificuldades dos cirurgiões-mor desempenharem os seus ofícios em Goiás, devido a sua população ser composta de mineiros e roceiros que desvalorizam tais habilidades, servindo-se de escravos enfermeiros para o tratamento de alguns males, 23/07/1774, Arquivo Histórico Ultramarino (AHU), Avulsos da Capitania de Goiás, cx. 27, doc. 1780.

${ }^{6}$ Embora aborde o Sudão oriental, o estudo de Evans-Pritchard (2005) sobre a bruxaria nos azandes é emblemático sobre esse assunto.

${ }^{7}$ Essa visão é defendida, entre outros, por Roger Bastide (1967).

8 "Chamados de feiticeiros nos documentos oficiais e na imprensa, os adivinhos, curandeiros e chefes de casa de culto foram alvo de perseguição sistemática pela polícia" (Reis, 2008, p. 19).

${ }^{9}$ Sobre as irmandades de africanos e crioulos em Goiás colonial, ver Mary Karasch (2010).
} 
século XVIII e outra da primeira década do século XIX. As principais questões que nortearam a pesquisa foram: quais eram as práticas religiosas realizadas por essas escravas em Goiás colonial? Em que medida as tradições religiosas africanas foram ressignificadas em território goiano? Qual modelo de análise histórico-antropológico se adequa aos dois casos analisados? Na esteira de historiadores como Gwedolyn Midlo Hall, defendemos que "os estudos da diáspora africana nas Américas precisam ser concretos e contextualizados", já que "os povos e suas culturas evoluíram e mudaram em ambos os lados do Atlântico" (HALL, 2017, p. 63).

\section{Estudos sobre os africanos em Goiás escravista}

Embora o tema da escravidão tenha sido abordado episodicamente por Luís Palacin e por memorialistas e historiadores diletantes, apenas a partir da década de 1980 é que a história da escravidão em Goiás passou a ser estudada mais atentamente. Em 1980, Gilka Salles defendeu a tese Economia e escravidão em Goiás colonial na Faculdade de Filosofia, Letras e Ciências Humanas da USP. Seu trabalho se inseriu na linha da História Econômica e, embora a autora tenha projetado um trabalho sobre as condições do escravo na economia aurífera de Goiás, a sua tese acabou se tornando um estudo da economia goiana na época colonial. Além da marginalidade da presença escrava em sua pesquisa, a influência da "Escola Paulista" levou Salles a considerar a escravidão como inexoravelmente violenta, o que ocasionava a resistência escrava que a autora parece identificar exclusivamente com o aquilombamento. A "agência escrava" de modo mais amplo não é enfocada - como ocorreria nos trabalhos de historiadores como Silvia Lara, Sidney Chalhoub, Robert Slenes, Eduardo Silva e João José Reis -, sendo a luz lançada sobre a conjuntura econômica e o "escravismo colonial mineiro". Por defender a tese de "refluxo demográfico" após a decadência da mineração, Salles sofreu as críticas de Nasr F. Chaul (1997), que apontou o aumento populacional em Goiás no século XIX, o que já havia sido notado por Luís Palacin (1994).

Orientado por Gilka Salles, Martiniano José da Silva defendeu, em 1998, a dissertação Quilombos do Brasil Central: séculos XVIII e XIX (1719-1888): introdução ao estudo da escravidão. Embora já impactado pelas críticas de Silvia Lara e Sidney Chalhoub à tese de coisificação do escravo, Silva não rompeu com a perspectiva anterior, adotando a linha de Clóvis Moura. A resistência escrava é associada à formação de quilombos, visão que não se coaduna à perspectiva de "negociação e conflito" proposta por João Reis e Eduardo Silva. Ao adotar o quilombo como o foco de análise, resgatando a tese de Moura, Silva deixa de lado todas as resistências cotidianas, como as fugas temporárias ${ }^{10}$, a diminuição do ritmo de trabalho, a simulação de enfermidades e etc.

O capítulo de Silva dedicado à discussão da procedência dos escravos goianos reproduz as categorias "bantos" e "sudaneses", consideradas ultrapassadas, e não analisa documentos primários. Embora dialogue com autores como Eugene Genovese e Roger Bastide, ampliando a discussão iniciada pelo trabalho de sua orientadora, Silva não rompe com a ênfase no caráter de extrema violência da escravidão, adotando a formação de quilombos como foco da análise. A sua busca por características "típicas", elementos culturais imobilizados, autênticos (ou "sobrevivências africanas", como na perspectiva de Melville Herskovits) também era contestada por análises (como a de

\footnotetext{
10 Nesse caso, era fundamental a atuação do "padrinho", homem influente na sociedade, a quem o escravo
} procurava para negociar o retorno à casa do senhor. 
João Reis) que se valiam do modelo de crioulização proposto por Sidney Mintz \& Richard Price. Por fim, cabe destacar a relação de Martiniano Silva, autor de obras mais antigas sobre os quilombos goianos, com o Movimento Negro Unificado, além do seu diálogo com Clóvis Moura e Abdias do Nascimento. A história que Silva escreveu sobre a escravidão em Goiás, portanto, deve ser compreendida também em vista da sua militância política (SILVA, 2008).

Mais recentemente, em 2008, Maria Lemke Loiola defendeu a dissertação Trajetórias para liberdade: escravos e libertos na capitania de Goiás, publicada em livro em 2009. O trabalho se insere nos marcos da microhistória italiana. Analisando os registros de batismos de escravos da capitania de Goiás, que cobrem o período de 1765 e 1820, Loiola constatou que, até 1790 (decadência da mineração), os africanos (minas) predominavam. Com a mudança do eixo das atividades econômicas para o campo, os crioulos (nascidos no Brasil) passaram a preponderar. A autora relaciona, assim, atividade mineradora e tráfico internacional de escravos. Constata que Goiás era o terceiro principal destino dos escravos saídos da Cidade da Bahia (Salvador) durante a segunda metade do século XVIII, o que colocava Goiás na posição de "trecho interno do tráfico atlântico". Como já salientamos, a prevalência dos escravos minas com base nos registros de batismo não deve ser sobrevalorizada, já que muitos pretos de nação Angola e Congo eram batizados em suas regiões de procedência.

Os dados trazidos à tona por Loiola são de grande importância para a nossa pesquisa, mas, embora integre a História Social dos africanos em Goiás à História da África, a autora não aborda as práticas culturais africanas. O nosso enfoque se aproximará, portanto, do trabalho de Cristina de Cássia Moraes, em cujo estudo "Devotos de Nuestra Señora del Rosário de los Hombres Negros y seguidores del Vudú: Los rituales en la Région de los Guayases al final del siglo XVIII" (2002) analisou a denúncia feita contra a escrava Margarida crioula, que, ao lado de alguns irmãos do Rosário, participava de rituais de vodum. Moraes analisa as ressignificações desse rito de origem daomeana em pleno sertão goiano, conectando as histórias dos africanos escravizados ou forros em Goiás à História da África (MORAES, 2002 p. 71-92). Nessa linha de pesquisa, buscamos as trajetórias e práticas culturais de sacerdotes e curandeiros em Goiás colonial.

Essa história das práticas culturais e dos fluxos e refluxos entre África e Brasil se insere na vertente analítica da chamada Diáspora Africana, tal como seguida no Brasil, por exemplo, por João José Reis (2008) ${ }^{11}$. Goiás, portanto, aparece aqui como um "braço interior do tráfico atlântico". Como "a história dos africanos no Brasil do tempo da escravidão, em grande parte, é escrita a partir de documentos policiais" (REIS, GOMES \& CARVALHO, 2010, p. 9), os personagens centrais de nossa pesquisa serão buscados em devassas, denúncias e processos-crime.

\section{Isabel Angola e Margarida Crioula: duas mandingueiras em Goiás Colonial}

De acordo com João Reis, os africanos eram adeptos de um "pluralismo religioso" (REIS, 2003) ${ }^{12}$. Assim, em África, poderíamos encontrar pessoas que cultuavam seus ancestrais e divindades da natureza, na linha das religiosidades africanas, mas que também traziam colares com trechos do Alcorão ou bentinhos de

\footnotetext{
${ }^{11}$ Cf., ainda, João José Reis, Flávio dos Santos Gomes \& Marcus J. M. de Carvalho (2010).

12 João José Reis (2003) enfatizou que esse "pluralismo religioso" não é sinônimo de "sincretismo" - já que os africanos diferenciavam as suas crenças religiosas.
} 
Nossa Senhora. Luis Nicolau Parés, a respeito dos jejes dos reinos de Alada, Uidá e Daomé, assinalou a tendência destes ao que chamou de "princípio de agregação", ou seja, à formação de cultos com múltiplas divindades. Esse dado aponta para um "alto grau de tolerância religiosa" que caracterizou o vodum. "O pluralismo e a tolerância persistem até hoje", afirma Parés. A atitude "flexível e aberta" dos jejes pode ser estendida aos iorubás (chamados de nagôs na Bahia) e às demais etnias classificadas debaixo do guarda-chuva "Mina", assim como os de nação "Angola" (angolas, congos, benguelas, moçambiques etc.). "A evidência histórica aponta para uma tradição religiosa multifacetada, fluida e eclética, em que práticas, valores e deuses atravessam fronteiras étnicas e linguísticas, gerando fluxos culturais" (PARÉS, 2016, p. 38).

Exemplos - e lócus - desse pluralismo religioso são as irmandades leigas fundadas por africanos no Brasil colonial e imperial. Para os angolanos escravizados que desembarcavam no ultramar português, as irmandades do Rosário representavam um elo com a sua região de origem. Logo, no interior das irmandades de Nossa Senhora do Rosário e de São Benedito, os africanos construíram uma vida associativa e religiosa que também estava ancorada nas tradições culturais do seu continente de origem (KARASCH, 2010, p. 1) 13. A eleição de reis e rainhas e as preocupações com o "cuidado adequado com o corpo", com os enterros e preces destinadas à alma após a morte nas irmandades do Rosário estão entre os assuntos mais abordados pelos pesquisadores ${ }^{14}$. Como salientam Elizabeth W. Kiddy e Patricia A. Mulvey, muitos africanos escravizados chegavam ao Brasil com a crença de que Nossa Senhora do Rosário era africana ("rainha de Angola"). Estavam também muito familiarizados com o rosário, usando-o em volta de seus pescoços e recitando-os em suas próprias linguagens. O rosário "servia como um 'talismã' contra o mal", criando uma sensação de lar, o que tornava os pretos Angolas muito apegados às "contas dos rosários" (KIDDY, 2005, p. 15 e 169; MULVEY, 1976, p. 285).

Em Goiás, as irmandades do Rosário foram fundadas em Vila Boa em 1730 e, no Arraial da Meia Ponte, em 1736. Ambas construíram as suas capelas com recursos de "esmolas". Outras irmandades do Rosário foram fundadas em Goiás em 1791 (Bonfim), 1762 (Pilar, S. José de Tocantins), 1769 (Santa Luzia) e 1777 (Carmo e Crixás) (Karasch, 2010, p. 3). O número de escravos preponderava no interior dessas associações até meados do século XIX, como aponta o exemplo da irmandade do Rosário de Vila Boa de Goiás, cuja maioria dos membros da sua mesa administrativa (ou seja, os "oficiais" - juízes, tesoureiros e procuradores - e os "irmãos de mesa") era cativa até $1860^{15}$. Diferente do que ocorria em outros espaços coloniais, em Goiás os compromissos das irmandades do Rosário não incluíam clausulas restringindo a entrada de algumas nações africanas ${ }^{16}$. Na Capitania de Goiás, as irmandades de

\footnotetext{
13 "A Igreja e o Estado tentaram manipular as irmandades para seus próprios fins, ou seja, para a conversão e controle da população negra potencialmente perigosa, entretanto, os irmãos e irmãs negros adaptaram as irmandades aos seus próprios objetivos: o contato com o mundo espiritual, a construção de comunidades e formação de uma nova identidade, pois na medida em que abandonavam a condição de angolanos, Congos ou Minas e se transformavam em forros, cujos filhos seriam pretos livres e pardos livres, os afrodescendentes continuam celebrando seus ancestrais e pretos velhos e a dançar em sua homenagem em rituais religiosos e congadas" (Karasch, 2010, p. 20-21).

${ }^{14}$ As autoridades coloniais permitiram às irmandades do Rosário eleger reis e rainhas, juízas e juízes negros, que serviam de liderança para as comunidades negras locais. Cf., por exemplo, Marina de Mello e Souza (2005, p. 79-98).

${ }^{15}$ Livro dos Termos de Mesa, Nossa Senhora do Rosário, 1826-1864, Biblioteca da Fundação Educacional da Cidade de Goiás (BFEG), Papéis Avulsos.

${ }^{16}$ Algumas irmandades de pretos distinguiam em seus compromissos os africanos por "nações": Angola, Congo, Mina, etc. Na Cidade da Bahia (atual Salvador), por exemplo, os Angolas se reuniam nas
} 
pretos aceitavam bororos (nação indígena) e permitiam que os crioulos fossem eleitos reis/rainhas.

Como notou Maria Inês Côrtes de Oliveira, os africanos e os crioulos que reproduziam as suas práticas religiosas ancestrais viviam no Novo Mundo uma espécie de "vida dupla": uma oficial, católica e livremente manifestada nos registros do período colonial e imperial (assentos paroquiais de batismo, óbito, casamentos e mortes, livros particulares de irmandades, como os citados acima, e ainda em documentos cartoriais como os testamentos), e outra "clandestina", africana ou afro-brasileira, perseguida pelas autoridades (e, por isso, não presentes nos documentos citados anteriormente) (Cf. OLIVEIRA, 1988). Sendo assim, os documentos que o historiador dispõe para escrever a história de sacerdotes e curandeiros africanos no Brasil colonial e imperial são os processos criminais, respectivamente, os inquisitoriais/episcopais e os policiais (Cf. MOTT, 1986, p. 123-147; Reis, 2008). São como denunciados ou réus de crimes (sacrilégios, pactos demoníacos, farsantes, etc.) que os agentes de nossa pesquisa figuram nos registros históricos. O silêncio das fontes goianas sobre os africanos, constatado em nossa pesquisa, se explica, assim, pela nossa busca da via religiosa "clandestina", não oficial. De todo modo, é interessante problematizar o silêncio existente até mesmo nas fontes policiais: teriam as autoridades coloniais e ultramarinas se preocupado prioritariamente com a questão indígena em Goiás ou com a expansão das fronteiras para oeste (deixando as transgressões religiosas dos africanos e seus descendentes em segundo plano)? As buscas que fizemos nos registros inquisitoriais disponibilizados para consulta online do Arquivo Nacional da Torre do Tombo trouxeram inúmeros casos de calunduzeiros e mandingueiros de diversas regiões do Brasil, mas não identificamos - até o momento - denúncias contra esses agentes religiosos africanos em Goiás. Nas investidas em arquivos goianos, os esforços não foram muito melhores. Mas encontramos dois registros com indícios de práticas religiosas africanas na Capitania de Goiás, os quais abordaremos a seguir.

O primeiro desses registros foi encontrado no Livro 10, intitulado "Rol dos Culpados. Prelazia de Goiás, 1783-1805", na seção de manuscritos do Instituto de Pesquisas e Estudos Históricos do Brasil Central (IPEHBC). Trata-se de uma escrava ${ }^{17}$ de nação Angola, por nome Isabel, presa a mando das autoridades diocesanas goianas aos 28 de julho de 1804. Isabel foi encarcerada pelas autoridades diocesanas por um "sacrilégio cometido [...] na Aldeia de São José". O sacrilégio consistiu em "tirar [...] uma partícula da boca que havia comungado sem observância de um despacho do Reverendo Vigário da Vara atual." Uma devassa foi aberta, mas Isabel acabou solta após quase um ano e meio de encarceramento, como comprova a "sentença proferida nos Autos de seu livramento em data de 17 de dezembro de 1805"18.

Embora esse registro não ofereça dados substanciais, que fomentem uma análise da trajetória da africana presa ou um aprofundamento de suas crenças e práticas religiosas, não deixa de ser interessante problematizar dois aspectos dessa devassa episcopal - na verdade, apenas um breve lançamento da africana no rol dos culpados,

irmandades do Rosário (da Conceição da Praia e do Pelourinho), os Jejes na Irmandade do Senhor do Bom Jesus das Necessidades e os Nagôs na Irmandade da Senhora da Boa Morte (Barroquinha) (Cf. Reis, 1991 e 1997, p. 7-33). Na Cidade do Rio de Janeiro, os Minas eram devotos de Nossa Senhora da Lampadosa e do Menino Jesus (na igreja de São Domingos) e os Minas Mahis de Daomé, os Sabarus e os Dagomés se reuniam na Irmandade de Santo Elesbão e Santa Ifigênia (Cf. Soares, 2000).

17 Isabel era escrava de Antônio Luís da Costa Sintra.

18 Rol dos Culpados. Prelazia de Goiás, 1783-1805, Instituto de Pesquisas e Estudos Históricos do Brasil Central (IPEHBC), Seção de manuscritos, Livro 10, fls. 17. 
pois não há uma transcrição da devassa. O primeiro e mais relevante indício presente nesse registro documental é o que as autoridades da Prelazia de Goiás chamaram de "sacrilégio", isto é, o fato de Isabel retirar uma parte da hóstia de sua boca após ter comungado. O que esse dado indica sobre as práticas e crenças religiosas africanas? Como assinala Luís Nicolau Parés, os africanos eram receptivos a aspectos sagrados -que eles entendiam como mágicos - de outras religiões (Cf. PARÉS, 2016). Assim, como nos informa Laura de Mello e Souza, os frequentes roubos de hóstias, objetos e paramentos específicos da consagração eucarística indicam o conhecimento dos africanos a respeito dos poderes do sacramento do altar (SOUZA, 1986). No Brasil Colonial, os africanos "furtaram hóstias consagradas, pedaços de pedra d'ara, de sanguinho e corporal tendo em vista a confecção de bolsas de mandinga que, segundo a crença popular, preservava dos perigos" (CAMPOS, 1996, p. 67-68) ${ }^{19}$.

Isabel, portanto, na visão das autoridades da Prelazia de Goiás, cometera um sacrilégio, mas, no seu próprio entender, apenas fez uso de um objeto mágico da "religião dos brancos" para incrementar a sua "bolsa de mandinga", aumentando a sua força vital e, assim, a sua bem-aventurança no mundo dos vivos - aspectos da cosmovisão Bantu, como assinalou Robert Daibert (2015, p. 7-25). Estamos diante, sem dúvida, de uma clara apropriação de elementos do catolicismo a partir de um prisma africano. Isabel, de "nação Angola", era, provavelmente, da etnia ambundo ou bakongo. Embora o termo "mandinga" reporte a um grupo étnico específico, que habitava a atual região de Guiné-Bissau, na África Ocidental, os "mandingueiros" não pertenciam apenas a esse grupo. Na realidade, os termos "mandinga" e "mandingueiro" se tornaram abrangentes, servindo para identificar todo tipo de "feitiçaria" e de "feiticeiro", respectivamente (SANTOS in Paiva \& SANTOS, 2013, p. 11-28). Quando conjugado ao termo "bolsa", "mandinga" se referia a um amuleto mágico que tinha 0 poder de "fechar o corpo". Como observou Vanicleia Silva Santos,

Dentre as práticas mágicas realizadas pelos africanos e crioulos no Império Português, tiveram destaque os amuletos em formato de bolsinha contendo ingredientes que protegiam contra armas e doenças. Sua popularidade atiçou os inquisidores do Santo Ofício que a denominou bolsa de mandinga, e os confeccionadores de mandingueiros, e interpretaram a prática como uma manifestação de feitiçaria. (SANTOS, 2008, s./p.)

A confecção dessas "bolsas" nas sociedades atlânticas consistiu em uma "recriação de tradições africanas no mundo do cativeiro" e demonstra uma "circulação de saberes entre africanos de diferentes origens, a partir de um fundamento da cultura banto associada ao cristianismo" (SANTOS, 2008, s./p.). Apesar de Isabel não ter sido caracterizada como "feiticeira", mas como "sacrílega", parece óbvia a finalidade do "roubo" (o tirar da boca) da hóstia sagrada. Outro indício da recorrência das práticas africanas em Goiás é o de que Isabel retirou da boca a hóstia "sem observância de um despacho do Reverendo Vigário da Vara atual." O que isto quer dizer? Que estamos diante de um "crime" recorrente na Prelazia de Goiás, já que mereceu um despacho oficial do vigário da vara sobre o roubo de hóstia e objetos sagrados - o que, conjeturamos, servia para a confecção das referidas bolsas de mandingas. Esse registro, embora lacônico, permite vislumbrar que - não obstante o silêncio das fontes

\footnotetext{
${ }^{19}$ Esse poder mágico ficaria mais eficaz ainda se o amuleto retornasse temporariamente para a mesa do altar: "que para ficar a mandinga bem forte a havia de meter entre a pedra d'ara e toalha do altar para se dizer missa sobre ela" (SOUZA, 1986, p. 224).
} 
sobre a nossa temática - as práticas religiosas e de curandeirismo dos africanos em Goiás colonial era frequente.

O segundo registro documental, também referente a uma escrava mandingueira, foi encontrado em um manuscrito do Arquivo Frei Simão Dorvi (AFSD), na cidade de Goiás:

Em 21 de fevereiro de 1783, foi processada Margarida crioula, escrava do falecido tenente coronel João Pinto Barbosa Pimentel, pela culpa que Ihe resultou da denúncia que dela deu ao advogado promotor do Juízo por portar uma bolsa de mandinga com cabelos e unhas de um inocente e por depois de sua encomendação realizar bruxarias no campo dos justiciados com comidas e bebidas ${ }^{20}$.

Dessa vez, estamos diante de uma crioula, o que relativiza a visão de que os escravos nascidos no Brasil eram sempre "ladinos" 21 nos costumes. Como ressalvou Luís Nicolau Parés, os crioulos de primeira geração, ou seja, filhos de pais africanos, podiam manter as tradições africanas no Novo Mundo, ainda que ressignificadas (PARÉS, 2005, p. 91-92). O “modelo pendular", bidirecional entre crioulização e africanização, proposto por Ira Berlin (1996, p. 251-288), também é salutar nesse sentido: quando os africanos predominavam em uma dada região da América, os crioulos poderiam africanizar-se ${ }^{22}$. Como Isabel, Margarida também teve o seu nome lançado no rol de culpados da Prelazia de Goiás, mas, diferente da primeira, foi denunciada como "mandingueira". O Advogado promotor do Juízo da Vila Boa de Goiás a acusou de "portar uma bolsa de mandinga", contendo "cabelos e unhas de um inocente" (ou seja, de uma criança). A manipulação de partes do corpo de uma criança com fins mágicos (realizados no campo dos justiciados) Ihe rendeu a alcunha de "bruxa". Embora também seja lacônico, esse registro liga a bolsa de mandinga à oferendas ("comidas e bebidas") e práticas mágicas africanas ("bruxarias") em local público. A falta de dados sobre a filiação de Margarida e de maiores indícios sobre as entidades para as quais foram feitas as oferendas (comidas e bebidas) não nós permite conjeturar a procedência africana das suas práticas religiosas. Tratar-se-ia de uma prática de calundu (ou seja, rituais com finalidades de cura ou adivinhação)? Sabemos que estas ocorriam, principalmente, em lugares privados (sobretudo, casas de libertos africanos ou crioulos). Estaríamos, então, diante do culto aos inquices dos futuros candomblés Bantu?

\section{Considerações finais}

Apesar de parcos, os registros encontrados são ilustrativos sobre as práticas africanas em Goiás, ensejando novas pesquisas sobre temática tão carente de estudos na historiografia goiana. Os indícios sobre as duas mandingueiras cativas torna inequívoca a realização de práticas religiosas africanas em solo goiano, conclusão que

\footnotetext{
${ }^{20}$ Rol de Culpados, 1780-1785, Arquivo Frei Simão Dorvi (AFSD), Documentos Avulsos, fls. 21 e $21 \mathrm{v}$.

21 "Ladino" era um sinônimo de "esperto" ou "capaz", consistindo em um termo empregado para designar o negro que conhecia a língua e os costumes da sociedade portuguesa. Aplicava-se, sobretudo, aos crioulos (ou seja, àqueles negros nascidos nas próprias sociedades em que viviam como escravos), mas também poderia ser usado para se referir aos africanos que já vinham "aportuguesados" da África (como é o caso de muitos angolanos e congoleses) ou que aprenderam rapidamente a língua e os costumes da sociedade portuguesa em que passaram a viver. Em oposição ao "negro ladino", o "negro boçal" era tido por "ignorante" porque desconhecia a língua e os costumes da sociedade portuguesa.

22 Isso ocorreu, por exemplo, em Salvador entre fins do século XVIII e inícios do XIX, como assinalou Luís Nicolau Parés (2005): como predominavam os nagôs, o ioruba tornou-se a "língua franca" da comunidade negra local.
} 
- se hoje parece óbvia - era negada pelos intelectuais goianos até, pelo menos, os anos 1970.

Os dois casos analisados - de Isabel e Margarida -, ambas caídas nas malhas do juízo eclesiástico da Prelazia de Goiás, sugerem algumas conclusões ainda preliminares: 1) apesar da maioria cativa de nação Mina, como aponta o estudo de Maria Lenke Loiola (2009), os congo-angolanos também estiveram presentes de modo a imprimir a sua contribuição à religiosidade africana ressignificada em solo goiano; 2) as práticas africanas ressignificadas, como a confecção de bolsas de mandingas, não se limitavam às regiões litorâneas, constituindo as Minas de Goiás - como as Minas Gerais, mas em menor grau - um "braço do tráfico atlântico de escravos"; 3) as práticas religiosas afro-brasileiras não foram exclusividade de africanos em Goiás, mas também de crioulos - o que sugere uma operacionalidade do "modelo pendular" de Ira Berlin, assim como a relativização da tese de completa ladinização dos crioulos, sobretudo, no caso dos "de primeira geração".

\section{Referências}

BASTIDE, Roger. Les Amériques noires: les civilisations africaines dans le Nouveau Monde. Paris: Payot, 1967.

BERLIN, Ira. From creole to african: Atlantic creoles and the origins of a african-american society in mainland North America. The William and Mary Quartely, vol. 52, n. 3, 1996, p. 251-288.

CAMPOS, Adalgisa Arantes. Irmandades Mineiras e Missas. Varia História, n. 16, set./1996, p. 67-68.

CHAUL, Nasr F. Caminhos de Goiás: da construção da "decadência" aos limites da "modernidade". Goiânia: Ed. da UFG / Ed. da UCG, 1997.

DAIBERT, Robert. A religião dos bantos: novas leituras sobre o calundu no Brasil colonial. Estudos Históricos, vol. 28, n. 55, 2015, p. 7-25.

ESCHWEGE, Wilhelm Ludwig von. Notícias e reflexões estatísticas da Província de Minas Gerais. Revista do Arquivo Público Mineiro, volume IV, 1899, s./p.

EVANS-PRITCHARD, E. E. A bruxaria, oráculos e magia entre os Azande, Rio de Janeiro: Zahar, 2005.

HALL, Gwendolyn Midlo. Cruzando o Atlântico: etnias africanas nas Américas. Topoi (UFRJ), vol. 6, n.10, 2005, p. 29-70.

HALL, Gwendolyn Midlo. Escravidão e etnias africanas nas Américas: restaurando os elos. Petrópolis, RJ: Vozes, 2017.

KARASCH, Mary. American Counterpoint: New Approaches to Slavery and Abolition in Brazil. In: The 12th Annual Gilder Lehrman Center International Conference at Yale University Co-sponsored with the Council on Latin American and Iberian Studies at Yale. New Haven, Connecticut: Yale University, 2010.

KARASCH, Mary. Construindo comunidades: as irmandades dos pretos e pardos no Brasil Colonial e em Goiás. In: The 12th Annual Gilder Lethrman Center International Conference at Yale University. New Haven, Connecticut, 2010. 
KIDDY, Elizabeth W. Blacks of the Rosário: memory and history in Minas Gerais, Brazil. Pennsylvania: Pennsylvania State University Press, 2005.

LAW, Robin. Etnia de africanos na diáspora: novas considerações sobre os significados do termo "mina". Tempo (UFF), vol. 10, n. 20, 2006, p. 98-120.

LEMES, Fernando Lobo. Goiás na arquitetura geopolítica da América portuguesa. Tempo (UFF), vol. 19, n. 35, 2013, p. 185-209.

LOIOLA, Maria Lemke. Trajetórias para liberdade: escravos e libertos na Capitania de Goiás. Goiânia: Editora UFG, 2009.

MORAES, Cristina de C. P. Devotos de Nuestra Señora del Rosário de los Hombres Negros y seguidores del Vudú: Los rituales sudaneses en la Región de los Guayases al final del siglo XVIII. In: ZAVALA, Maria T. Cortés, et.al. (coords.). Región, Frontera y Prácticas Culturales en la Historia de América Latina y el Caribe. Michoacan, México: Universidad Michoacan de San Nicolas de Hidalgo; Goiânia: UFG/CECAB, 2002, p. 7192.

MOTT, Luiz. Acotundá: raízes setecentistas do sincretismo afro-brasileiro. Anais do Museu Paulista, nova série, volume XXXI, São Paulo, 1986, p. 123-147.

MULVEY, Patricia A. Black lay brotherhoods of colonial Brazil: a history. Tese (Ph.D. em História). New York: University of New York, 1976.

OLIVEIRA, Maria Inês Côrtes de. O Liberto: o seu mundo e os outros. Salvador, 1790/1890. Salvador: Corrupio, 1988.

PALACIN, Luís. Goiás: 1722-1822 - Goiás: Estrutura e Conjuntura numa Capitania de Minas. Tese (Livre Docência em História). Goiânia: Universidade Federal de Goiás, 1972.

PALACIN, Luís. Século do Ouro em Goiás: 1722-1822. Goiânia: Ed. da UCG, 1994.

PARÉS, Luis Nicolau. O processo de crioulização no Recôncavo Baiano (1750-1800). Afro-Ásia, n. 33, 2005, p. 91-92.

PARÉS, Luis Nicolau. O rei, o pai e a morte: a religião vodum na antiga Costa dos Escravos na África Ocidental. São Paulo: Companhia das Letras, 2016.

REIS, João José. A morte é uma festa: ritos fúnebres e revolta popular no Brasil do século XIX. São Paulo: Companhia das Letras, 1991.

REIS, João José. Domingos Sodré, um sacerdote africano: escravidão, liberdade e candomblé na Bahia do século XIX. São Paulo: Companhia das Letras, 2008.

REIS, João José. Identidade e diversidade étnica nas irmandades negras no tempo da escravidão. Tempo (UFF), vol. 2, n. 3, 1997, p. 7-33.

REIS, João José; GOMES, Flávio dos Santos \& CARVALHO, Marcus J. M. de. O alufá Rufino: tráfico, escravidão e liberdade no Atlântico Negro (c.1822-c.1853). São Paulo: Companhia das Letras, 2010.

REIS, João José. Rebelião escrava no Brasil. A história do levante dos malês (1835). São Paulo: Companhia das Letras, 2003. 
SANTOS, Vanicleia Silva. As bolsas de mandinga no espaço atlântico: século XVIII. Tese (Doutorado em História). São Paulo: Universidade de São Paulo, 2008.

SANTOS, Vanicleia Silva. Mandingueiro não é Mandinga: o debate entre nação, etnia e outras denominações atribuídas aos africanos no contexto do tráfico de escravos. In: PAIVA, Eduardo França, SANTOS, Vanicleia Silva (Orgs.). África e Brasil no mundo moderno. São Paulo: Annablume, 2013, p. 11-28.

SILVA, Martiniano J. Quilombos do Brasil Central: violência e resistência escrava, 17191888. Goiânia: Kelps, 2008.

SILVEIRA, Renato da. Nação africana no Brasil escravista: problemas teóricos e metodológicos. Afro-Ásia, n. 38, 2008, p. 245-301.

SOARES, Mariza de Carvalho. Devotos da cor - identidade étnica, religiosidade e escravidão no Rio de Janeiro, século XVIII, Rio de Janeiro: Civilização Brasileira, 2000.

SOUZA, Laura de Mello e. O Diabo na Terra da Santa Cruz. São Paulo: Companhia das Letras, 1986.

SOUZA, Marina de Mello e. Reis do Congo no Brasil, Séculos XVIII e XIX. Revista de História (USP), n. 152, vol. 1 2005, p. 79-98.

\section{Notas de autoria}

Daniel Precioso é doutor em História pela Universidade Federal Fluminense (2014). Docente do Programa de Pós-Graduação em História da Universidade Estadual de Goiás (PPGHIS/UEG-Morrinhos). O artigo apresenta alguns dos resultados alcançados no âmbito do projeto de pesquisa (interno - PrP/UEG) Alufás, "feiticeiros" e mandingueiros: trajetórias e práticas culturais de sacerdotes e curandeiros africanos em Goiás colonial e imperial (1720-1850), desenvolvido e coordenado pelo autor entre 2017 e 2019. E-mail: daniel.precioso@gmail.com.

\section{Como citar esse artigo de acordo com as normas da revista}

PRECIOSO, Daniel. Isabel Angola e Margarida Crioula: duas escravas mandingueiras na Capitania de Goiás (1783-1804). Sæculum - Revista de História, v. 24, n 41, p. 99110, 2019.

\section{Contribuição de autoria}

Não se aplica.

\section{Consentimento de uso de imagem}

Não se aplica.

\section{Aprovação de comitê de ética em pesquisa}

Não se aplica.

\section{Licença de uso}

Este artigo está licenciado sob a Licença Creative Commons CC-BY. Com essa licença você pode compartilhar, adaptar, criar para qualquer fim, desde que atribua a autoria da obra.

\section{Histórico}

Recebido em 20/02/2019.

Aprovado em 23/09/2019. 